\title{
Effects of feeding a high-fiber byproduct feedstuff as a substitute for barley grain on rumen fermentation and productivity of dairy cows in early lactation
}

\author{
Y. Sun and M. Oba ${ }^{1}$ \\ Department of Agricultural, Food and Nutritional Science, University of Alberta, Edmonton, AB, T6G 2P5 Canada
}

\begin{abstract}
The objective of the study was to evaluate effects of partial substitution of dietary grain with wheat dried distillers grains with solubles (DDGS) on dry matter intake (DMI), sorting behavior, rumen fermentation, apparent total-tract nutrient digestibility, plasma metabolites, and milk production of dairy cows in early lactation. Sixty-one Holstein cows, including 13 ruminally cannulated cows, were blocked by parity and calving date and assigned to 1 of 2 experimental diets immediately after calving until $12 \mathrm{wk}$ in lactation. The control $(\mathrm{CON})$ diet contained $43 \%$ barley silage, $17.3 \%$ dry-rolled barley grain, and $39.7 \%$ concentrate mix on a dry matter basis, and wheat DDGS replaced dryrolled barley grain in the DDGS diet. Dietary starch content was 29.2 and $19.1 \%$ for CON and DDGS diets, respectively. Despite the 10-percentage-unit difference in dietary starch content, cows fed the DDGS diet did not increase ruminal $\mathrm{pH}$. A significant treatment by parity interaction was observed for DMI; feeding the DDGS diet decreased DMI of multiparous cows compared with CON (20.1 vs. $21.3 \mathrm{~kg} / \mathrm{d}$ ) but increased that of primiparous cows (16.2 vs. $14.7 \mathrm{~kg} / \mathrm{d})$. Although milk yield was not affected by treatment, cows fed the DDGS diet had lower apparent total-tract digestibility of starch compared with CON (81.9 vs. $91.2 \%)$ and tended to have higher plasma concentrations of nonesterified fatty acids (173 vs. $143 \mathrm{mEq} / \mathrm{L}$ ). High-fiber byproduct feedstuffs such as wheat DDGS can be used as a partial substitute for grains in diets of dairy cows in early lactation but the substitution may not mitigate rumen acidosis problems and may decrease energy intake of multiparous cows in early lactation.
\end{abstract}

Key words: early lactation, starch, high-fiber byproduct, wheat dried distillers grains with solubles (DDGS)

Received May 26, 2013.

Accepted November 9, 2013.

${ }^{1}$ Corresponding author: Masahito.Oba@ales.ualberta.ca

\section{INTRODUCTION}

High-producing dairy cows often experience negative energy balance after calving (Grummer, 1995; NRC, 2001). High-grain diets are usually fed to cows in early lactation to increase their energy intake, but that often increases the incidence of acidosis and laminitis (Nocek, 1997) and decreases milk production (Krause and Oetzel, 2006). Most high-producing dairy cows are at risk of SARA, a common digestive disorder (Nocek, 1997) usually caused by feeding a diet containing highly fermentable carbohydrates with insufficient physically effective fiber (NRC, 2001). Early lactating dairy cows have greater risk of rumen acidosis because their diets change from a high-forage to a high-starch diet immediately after calving. When cows are fed rapidly fermentable grain, their DMI often decreases because of excess acid production in the rumen (Allen, 2000). The reduction in DMI caused by subclinical acidosis often decreases energy intake, and may worsen negative energy balance. Therefore, it is challenging to maximize energy intake of dairy cows in early lactation without causing SARA.

Dried distillers grains with solubles (DDGS) is a byproduct of the ethanol industry that contains high CP and digestible NDF (Schingoethe et al., 2009). Although DDGS is widely accepted as a dietary protein source, some researchers used DDGS to replace grain in the diet fed to dairy cows. Janicek et al. (2008) used DDGS to replace both forage and concentrate and found that DMI and milk production increased linearly with increasing dietary allocations of DDGS $(0,10,20$, and 30\%), indicating that DDGS might be an option as a substitute for grain to increase DMI and energy intake. However, Ranathunga et al. (2010) used soyhulls and DDGS to replace corn grain, and they found that DMI decreased linearly as dietary NDF content increased, but milk production was not affected; causes for this discrepancy are not known. Feeding DDGS to replace grain in dairy diets would reduce dietary starch concentration and increase NDF concentration, and ruminal $\mathrm{pH}$ would also be expected to increase. Zhang et al. (2010) found that ruminal $\mathrm{pH}$ tended to increase when wheat DDGS was used to replace barley grain at 
$20 \%$ of dietary DM in the diets for mid-lactation dairy cows.

Maximizing energy intake of dairy cows in early lactation without causing SARA is a challenge, but the effects of feeding high-fiber byproducts as a substitute for grain on productivity of dairy cows in early lactation have not been extensively studied. Based on previous research using cows in mid lactation, we hypothesized that reducing the dietary starch content by replacement of barley grain with wheat DDGS would increase ruminal $\mathrm{pH}$, DMI, and milk production of dairy cows in early lactation. The objective of the study was to evaluate effects of dietary starch content, which was accomplished by partial substitution of dietary grain with wheat DDGS, on DMI, sorting behavior, rumen fermentation, apparent total-tract nutrient digestibility, plasma metabolites, and milk production of dairy cows in early lactation.

\section{MATERIALS AND METHODS}

This experiment was conducted at the Dairy Research and Technology Center at the University of Alberta (Edmonton, Alberta, Canada). All procedures were preapproved by the Animal Care and Use Committee for Livestock at the University of Alberta and conducted according to the guidelines of the Canadian Council of Animal Care (2009).

\section{Diets, Animals, and Experimental Design}

Two experimental diets were formulated for this study. The control (CON) diet contained $43 \%$ barley silage, $17.3 \%$ dry-rolled barley grain, and $39.7 \%$ concentrate mix on a DM basis, and wheat DDGS replaced dry-rolled barley grain in the DDGS diet (Table 1). As wheat DDGS contained more CP and fat compared with barley grain, dietary contents of beet pulp, corn gluten meal, urea, and vegetable oil were adjusted to decrease the differences in dietary $\mathrm{CP}$ and fat concentrations between the CON and DDGS diets. Both diets were formulated according to NRC (2001) to meet or exceed the nutritional requirements for early lactating cows $(650 \mathrm{~kg}$ of BW) producing $45.0 \mathrm{~kg}$ of milk/d with $3.50 \%$ milk fat and $3.00 \%$ milk protein. Particle size distribution of the TMR was determined for $3 \mathrm{~d}$ each week by using the Penn State Particle Separator. Both diets had similar physically effective factors, but the DDGS diet had more fine particles collected in the pan (28.0 vs. $10.8 \%$ ). The DM concentration of barley silage and concentrate mixes were determined weekly and diet formulations adjusted if necessary.

Sixty-one Holstein cows (22 primiparous and 39 multiparous cows) were blocked by parity and calving date and assigned to 1 of 2 experimental diets $(\mathrm{n}=30$ for $\mathrm{CON} ; \mathrm{n}=31$ for DDGS) immediately after calving until $12 \mathrm{wk}$ in lactation. Of the 61 cows used in this study, 13 multiparous cows were ruminally cannulated $(\mathrm{n}=6$ for CON; $\mathrm{n}=7$ for DDGS). Data were removed from any week when cows had health problems and were treated with antibiotics. Cows were housed individually in tie stalls and allowed to exercise outside for $2 \mathrm{~h}$ daily except on weekends. All cows were fed experimental diets as TMR and had free access to water. Cows were fed once daily at 105 to $110 \%$ of expected intake. Cows were milked in their stalls twice daily at 0400 and $1600 \mathrm{~h}$.

\section{Data and Sample Collection}

Data and samples were collected on Tuesday, Wednesday, and Thursday every week. The amount of feed offered was recorded, and diet ingredients and TMR were sampled daily during the sample collection periods. At the end of the sample collection period, daily samples were composited to obtain a representative sample for each week. Orts were sampled from each

Table 1. Ingredients, nutrient composition, and particle size distribution of experimental diets ${ }^{1}$

\begin{tabular}{lcc}
\hline Item & CON & DDGS \\
\hline Ingredients, \% of DM & & \\
Barley silage & 43.0 & 43.1 \\
Corn grain, rolled & 21.6 & 21.6 \\
Barley grain, rolled & 17.3 & - \\
Wheat DDGS & - & 17.2 \\
Corn gluten meal & 8.3 & - \\
Urea & 0.3 & - \\
Beet pulp & 3.2 & 12.3 \\
Vegetable oil & 2.4 & 1.9 \\
Mineral and vitamin mix ${ }^{2}$ & 3.9 & 3.9 \\
Nutrient composition & 50.1 & \\
DM, \% & 89.1 & 50.0 \\
OM, \% of DM & 17.3 & 89.1 \\
CP, \% of DM & 27.2 & 19.4 \\
NDF, \% of DM & 29.2 & 30.5 \\
Starch, \% of DM & 3.7 & 19.1 \\
Ether extract, \% of DM & 33.9 & 4.4 \\
NFC, \% of DM & 0.24 & 38.3 \\
S, \% of DM & & 0.54 \\
Particle size distribution, \% as fed & 16.5 & \\
19 mm & 27.5 & 16.5 \\
8 mm & 45.2 & 28.3 \\
1.18 mm & 10.8 & 27.2 \\
Pan & 44.0 & 28.0 \\
Physically effective factor ${ }^{3}$ & 44.8 \\
\hline CON
\end{tabular}

${ }^{1} \mathrm{CON}=$ control diet; DDGS $=$ diet containing wheat-based dried distillers grains with solubles at $17 \%$ of dietary DM.

${ }^{2}$ Mineral and vitamin mix contained $1.73 \% \mathrm{Ca}, 0.47 \% \mathrm{P}, 1.14 \% \mathrm{Na}$, $0.50 \% \mathrm{Mg}, 2.14 \% \mathrm{Cl}, 1.66 \% \mathrm{~K}, 0.75 \mathrm{mg} / \mathrm{kg}$ of $\mathrm{Co}, 16.6 \mathrm{mg} / \mathrm{kg}$ of $\mathrm{Cu}$, $0.63 \mathrm{mg} / \mathrm{kg}$ of I, $396 \mathrm{mg} / \mathrm{kg}$ of Fe, $56.3 \mathrm{mg} / \mathrm{kg}$ of Mn, $0.31 \mathrm{mg} / \mathrm{kg}$ of $\mathrm{Se}, 55.7 \mathrm{mg} / \mathrm{kg}$ of Zn, $22.6 \mathrm{kIU} / \mathrm{kg}$ of vitamin A, $2.3 \mathrm{kIU} / \mathrm{kg}$ of vitamin $\mathrm{D}, 74.7 \mathrm{IU} / \mathrm{kg}$ of vitamin $\mathrm{E}$.

${ }^{3}$ Determined as the proportion of particles retained on 19- and 8-mm sieves (Lammers et al., 1996). 
cow daily (Wednesday, Thursday, and Friday before feeding) and daily samples were composited to obtain a representative sample for each cow each week. The composited orts samples were separated into 2 parts, one to determine chemical composition and the other to determine particle size distribution. The Penn State Particle Separator was used to measure particle size distribution of feed ingredients (Lammers et al., 1996) and orts, and the sorting index was determined for each particle category according to Leonardi and Armentano (2003): sorting index $=$ actual DMI/expected DMI $\times$ 100.

Body weight and BCS (5-point scale; $1=$ thin and 5 $=$ fat; Wildman et al., 1982) were measured $1 \mathrm{wk}$ before calving. The BW was $700 \pm 90.0$ and $706 \pm 81.1 \mathrm{~kg}$ and BCS was $3.53 \pm 0.52$ and $3.77 \pm 0.61$, respectively, for cows on the CON and DDGS treatments (mean \pm SD). After calving, BW was measured twice a week at $0700 \mathrm{~h}$, after milking but before feeding, on Tuesday and Thursday. The average of the $2 \mathrm{BW}$ measurements was used as the data for each week. Body condition score was also determined for each collection period. Milk yield was recorded daily and milk samples were collected 6 times during the sample collection period consecutively from Tuesday p.m. to Friday a.m.

Blood was sampled weekly from the coccygeal vessels every $18 \mathrm{~h}$ over $3 \mathrm{~d}$ (Tuesday at $1300 \mathrm{~h}$, Wednesday at $0700 \mathrm{~h}$, Thursday at $0100 \mathrm{~h}$, and Thursday at 1900 h) using BD Vacutainer tubes (Becton Dickinson Co., Franklin Lakes, NJ) containing Na heparin. Blood samples were immediately centrifuged at $4^{\circ} \mathrm{C}$ at $3,000 \times g$ for $20 \mathrm{~min}$. Four plasma samples collected during the collection period were composited to yield one sample per cow per week and stored at $-20^{\circ} \mathrm{C}$ until analysis.

For the 13 ruminally cannulated cows, ruminal $\mathrm{pH}$ was measured every $30 \mathrm{~s}$ for $72 \mathrm{~h}$ using the LRC ruminal $\mathrm{pH}$ data logger system (Penner et al., 2006). Rumen fluid $(15 \mathrm{~mL})$ was collected every $9 \mathrm{~h}$ over a $72-\mathrm{h}$ period of each experimental period (1300 and $2200 \mathrm{~h}$ on Tuesday; 0700 and $1600 \mathrm{~h}$ on Wednesday; 0100, 1000, and $1900 \mathrm{~h}$ on Thursday; and $0400 \mathrm{~h}$ on Friday). Each rumen fluid sample was collected from the cranial, ventral, and caudal regions, and filtered through a double layer of perforated nylon screen. Filtered rumen fluid samples were placed on ice immediately after collection and centrifuged at $4^{\circ} \mathrm{C}$ at $3,000 \times g$ for $20 \mathrm{~min}$. Samples were stored at $-20^{\circ} \mathrm{C}$ until analysis. Immediately before analysis, 8 rumen fluid samples collected from each cow were composited to yield one representative sample for each week. In addition, fecal samples were collected from the rectum every $9 \mathrm{~h}$ over a 72 -h period at the same time as rumen fluid collection, and the samples were composited to yield one sample per cow per week.

\section{Sample Analysis}

Milk samples were analyzed at the Alberta Central Milk Testing Laboratory (Edmonton, AB, Canada) for milk fat, $\mathrm{CP}$, lactose, MUN, and SCC contents (AOAC International, 2002). The ECM yield was calculated according to the equation described by Tyrrell and Reid $(1965): \mathrm{ECM}=[0.327 \times$ milk yield $(\mathrm{kg})+12.95 \times$ fat yield $(\mathrm{kg})+7.2 \times$ protein yield] .

Plasma samples were analyzed for glucose, BHBA, NEFA, and urea $\mathrm{N}$ concentrations. Plasma glucose concentration was measured using a glucose oxidaseperoxidase enzyme (P7119, Sigma, St. Louis, MO) and dianisidine dihydrochloride (F5803, Sigma). Absorbance was determined by a plate reader (SpectraMax 190, Molecular Devices Corp., Sunnyvale, CA). Enzymatic oxidation to acetoacetate with 3-hydroxybutrate dehydrogenase (H6501, Roche, Mississauga, ON, Canada) was used to measure plasma BHBA concentration. Concentration of NEFA was determined using a commercial kit (NEFA C kit, Wako Pure Chemical Industries Ltd., Richmond, VA) as described by Johnson and Peter (1993). The concentration of plasma urea $\mathrm{N}$ was determined according to Fawcett and Scott (1960).

Samples of feed ingredients, orts, and feces were dried in a forced-air oven at $55^{\circ} \mathrm{C}$ for $48 \mathrm{~h}$ to determine DM, and then samples were ground through a $1-\mathrm{mm}$ screen using a Wiley mill (Thomas-Wiley, Philadelphia, PA). Ground samples were used for chemical analysis. Samples were further dried at $135^{\circ} \mathrm{C}$ for $2 \mathrm{~h}$ to determine analytical DM. Dried samples were oxidized in a muffle furnace for $2 \mathrm{~h}$ at $600^{\circ} \mathrm{C}$ (AOAC International, 2002; method 942.05) to determine OM concentration. The $\mathrm{CP}$ concentration was determined using a Leco analyzer (Leco FP-2000 N Analyzer; Leco Instrument Inc., St. Joseph, MI; Rhee, 2005). The concentration of NDF was determined using heat-stable amylase and sodium sulfite (Van Soest et al., 1991). Starch concentration was measured by the method described by Karkalas (1985). A Goldfisch extraction apparatus (Labconco, Kansas City, MO) with petroleum ether was used to measure ether extract concentration. To determine indigestible NDF, samples were placed in nitrogen-free polyester bags $(5 \times 10 \mathrm{~cm}$, pore size $=50 \mu \mathrm{m}$; R510, Ankom Technology, Macedon, NY) and incubated in the rumen for $120 \mathrm{~h}$. Indigestible NDF was used as an internal marker to calculate apparent total-tract digestibility (Cochran et al., 1986).

Rumen fluid samples were analyzed for VFA concentration by gas chromatography (Khorasani et al., 1996). Rumen $\mathrm{NH}_{3}-\mathrm{N}$ concentration was determined by the method described by Fawcett and Scott (1960). 
Table 2. Effects of replacing barley grain with wheat dried distillers grains (DDGS) with solubles in diets for early lactating cows on DMI, BW, BCS, and sorting behavior ${ }^{1}$

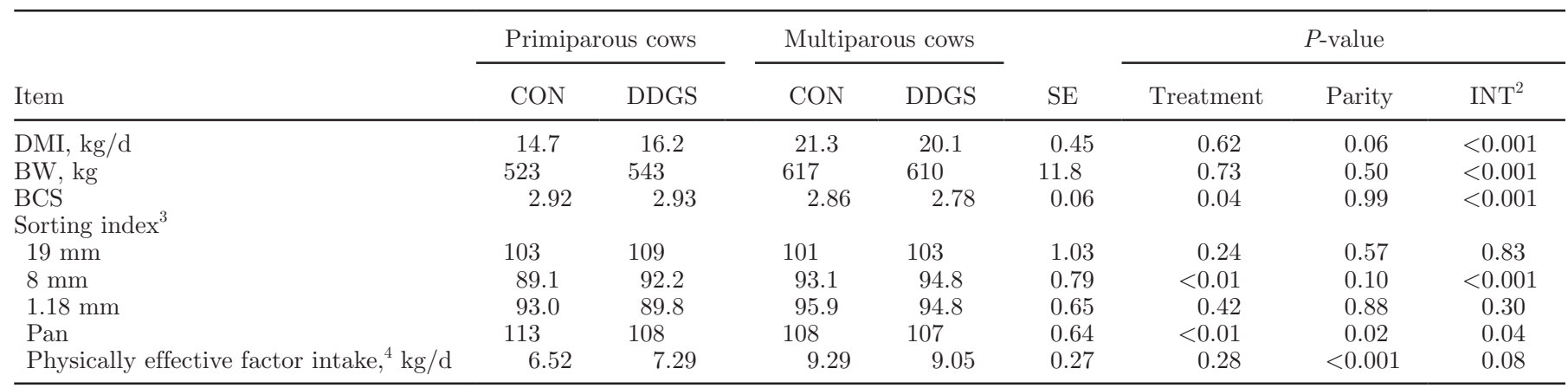

${ }^{1} \mathrm{CON}=$ control diet; DDGS = diet containing wheat-based dried distillers grains with solubles at $17 \%$ of dietary DM.

${ }^{2}$ Diet $\times$ parity interaction.

${ }^{3}$ Sorting index $>100$ indicates sorting for particles and that $<100$ indicates sorting against particles (Leonardi and Armentano, 2003).

${ }^{4}$ Intake of particles retained on 19- and 8-mm sieves (Lammers et al., 1996).

\section{Statistical Analysis}

The data collected from ruminally cannulated cows (i.e., total-tract digestibility and rumen fermentation variables) were analyzed using the following model:

$$
\mathrm{Y}_{\mathrm{ij}}=\mu+\mathrm{T}_{\mathrm{i}}+\mathrm{W}_{\mathrm{j}}+\mathrm{TW}_{\mathrm{ij}}+\mathrm{Cov}+\mathrm{e}_{\mathrm{ij}}
$$

where $Y_{i j}$ is the dependent variable, $\mu$ is the overall mean, $T_{i}$ is the fixed effect of treatment, $W_{j}$ is the fixed effect of week, $\mathrm{TW}_{\mathrm{ij}}$ is the effect of treatment by week interaction, Cov is the BCS before calving used as a covariate, and $\mathrm{e}_{\mathrm{ij}}$ is the residual. Body condition score was used as a covariate because it affects feed intake and animal health during the calving transition period (Hayirli et al., 2002). Week of lactation was used as a repeated measure. Treatment effects were declared significant at $P \leq 0.05$ and a tendency was declared at $0.05<P \leq 0.10$.

The other data were analyzed using PROC MIXED of SAS (version 9.2, SAS Institute Inc., Cary, NC) according to the following model:

$$
\begin{aligned}
\mathrm{Y}_{\mathrm{ijk}}=\mu & +\mathrm{T}_{\mathrm{i}}+\mathrm{W}_{\mathrm{j}}+\mathrm{P}_{\mathrm{k}}+\mathrm{TW}_{\mathrm{ij}}+\mathrm{WP}_{\mathrm{jk}} \\
& +\mathrm{TWP}_{\mathrm{ijk}}+\operatorname{Cov}+\mathrm{e}_{\mathrm{ijk}},
\end{aligned}
$$

where $Y_{i j k}$ is the dependent variable, $\mu$ is the overall mean, $T_{i}$ is the fixed effect of treatment, $W_{j}$ is the fixed effect of week used as a repeated measure, $\mathrm{P}_{\mathrm{k}}$ is the fixed effect of parity, $\mathrm{TW}_{\mathrm{ij}}$ is the effect of treatment by week interaction, $\mathrm{WP}_{\mathrm{jk}}$ is the effect of week by parity interaction, $\mathrm{TWP}_{\mathrm{ijk}}$ is the effect of treatments by week by parity interaction, Cov is the BCS before calving used as a covariate, and $\mathrm{e}_{\mathrm{ijk}}$ is the residual. Treatment effects were declared significant at $P \leq 0.05$ and tendencies were declared at $0.05<P \leq 0.10$.

\section{RESULTS}

A treatment by parity interaction was observed for DMI, BW, BCS, and sorting index (Table 2). The DDGS diet increased DMI for primiparous cows but decreased it for multiparous cows. In addition, multiparous cows fed the DDGS diet had lower BCS, whereas treatment for primiparous cows did not affect BCS. We observed no treatment effects on sorting for particle size on the 19-mm screen. Cows in the DDGS group sorted against particles retained on the 8 -mm screen and for the finest particles (collected in the pan) to a lesser extent compared with those in the CON group, and the extent of sorting was greater for primiparous cows compared with multiparous cows. These results showed that cows fed the DDGS diet preferentially consumed physically effective fiber compared with CON cows.

We observed no treatment effects on concentrations of plasma glucose or BHBA. Cows fed the DDGS diet tended to have higher NEFA concentrations compared with cows fed the CON diet (173 vs. $142 \mathrm{mEq} / \mathrm{L}, P$ $=0.08$; Table 3 ). Interestingly, we found an interaction among treatment, parity, and week $(P=0.02)$. For primiparous cows, plasma concentration of NEFA of cows on DDGS diet was higher at wk 2, 6, and 8

Table 3. Effects of replacing barley grain with wheat dried distillers grains (DDGS) in diets for early lactating cows on plasma metabolite concentrations $^{1}$

\begin{tabular}{lcccc}
\hline Item & CON & DDGS & SE & $P$-value \\
\hline Glucose, mg/dL & 53.4 & 53.6 & 1.10 & 0.67 \\
BHBA, mg/dL & 7.25 & 8.34 & 0.58 & 0.19 \\
NEFA, ${ }^{2} \mathrm{mEq} / \mathrm{L}$ & 143 & 173 & 11.6 & 0.08 \\
Urea-N, mg/dL & 5.46 & 6.58 & 0.40 & 0.81 \\
\hline
\end{tabular}

${ }^{1} \mathrm{CON}=$ control diet; DDGS = diet containing wheat-based dried distillers grains with solubles at $17 \%$ of dietary DM.

${ }^{2}$ Diet $\times$ parity $\times$ week interaction was significant $(P=0.02)$. See Figures 1 and 2 . 


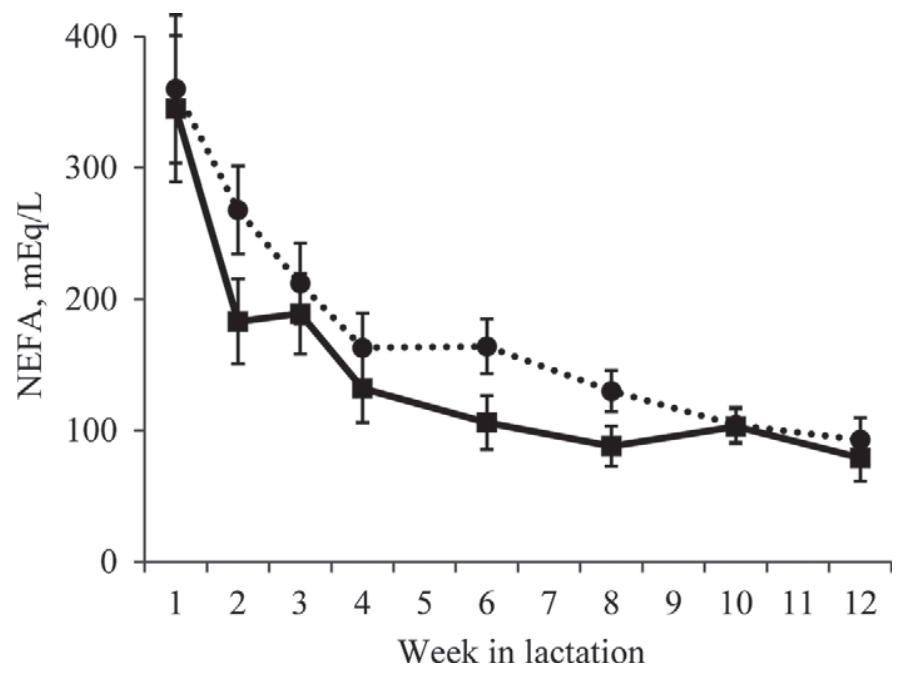

Figure 1. Effects of replacing barley grain with dried distillers grains with solubles (DDGS) in diets for early lactating primiparous cows on plasma NEFA concentration: control (ם) or DDGS $(\bullet)$.

compared with cows on the CON diet (Figure 1). For multiparous cows, cows on the DDGS diet had higher NEFA concentrations than cows on the CON diet at wk 3 and 4 (Figure 2).

Milk and milk component yields were not affected by treatment (Table 4). Milk lactose content was lower for cows fed DDGS compared with those fed the CON diet (4.64 vs. $4.73 \%$ ), but milk fat, CP, MUN, and SCC were not affected by treatment.

We observed no treatment effects on mean, minimum, or maximum ruminal $\mathrm{pH}$ (Table 5). Also, the area and duration of ruminal $\mathrm{pH}$ below 5.8 did not differ between treatments. However, cows fed the DDGS diet tended to have higher total VFA concentration in rumen fluid compared with cows fed the CON diet (107 vs. 116 $\mathrm{m} M ; P=0.06)$. The molar proportions of acetate $(55.8$ vs. $57.0 \mathrm{~mol} / 100 \mathrm{~mol} ; P=0.07)$ and butyrate (12.8 vs.

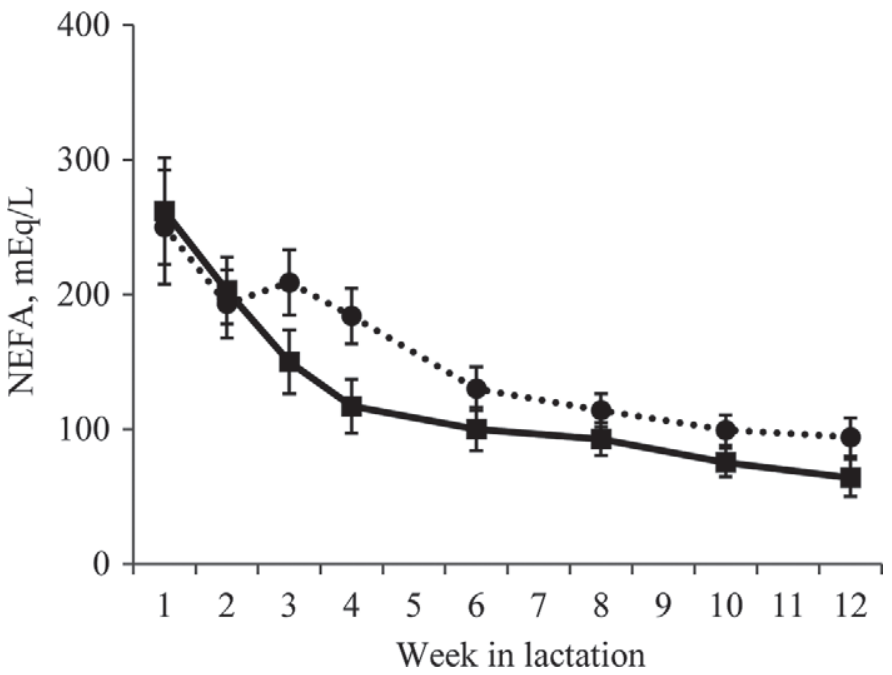

Figure 2. Effects of replacing barley grain with dried distillers grains with solubles (DDGS) in diets for early lactating multiparous cows on plasma NEFA concentration: control $(\mathbf{\square})$ or DDGS $(\mathbf{\bullet})$.

$13.1 \mathrm{~mol} / 100 \mathrm{~mol} ; P=0.08)$ tended to be higher for the DDGS treatment. The molar proportion of isovalerate in the DDGS diet was lower than that in the CON diet (1.70 vs. $1.20 \mathrm{~mol} / 100 \mathrm{~mol})$. Treatment had no other effects on other VFA or rumen $\mathrm{NH}_{3}-\mathrm{N}$ concentration.

Cows fed the DDGS diet tended to have higher totaltract CP digestibility (56.9 vs. $46.4 \% ; P=0.06$ ) but lower starch digestibility ( 81.9 vs. $91.2 \%$ ) compared with cows fed the CON diet (Table 6), but treatment had no effect on the digestibility of DM, OM, or NDF.

\section{DISCUSSION}

\section{Effects on Ruminal pH}

Cows in early lactation often experience severe ruminal acidosis (Fairfield et al., 2007; Penner et al., 2007; Penner and Oba, 2009). Ruminal $\mathrm{pH}$ is expected to

Table 4. Effects of replacing barley grain with wheat dried distillers grains (DDGS) in diets for early lactating cows on BW and lactation performance ${ }^{1}$

\begin{tabular}{lcccc}
\hline Item & CON & DDGS & SE & $P$-value \\
\hline Yield, kg/d & & & & \\
Milk & 35.3 & 34.9 & 1.03 & 0.83 \\
Milk fat & 1.33 & 1.31 & 0.05 & 0.85 \\
Milk CP & 0.97 & 0.97 & 0.03 & 1.00 \\
Milk lactose & 1.67 & 1.63 & 0.05 & 0.57 \\
ECM ${ }^{2}$ & 35.6 & 35.4 & 1.03 & 0.88 \\
Milk composition, $\%$ & 3.84 & 3.79 & 0.10 & 0.75 \\
Fat & 2.77 & 2.80 & 0.03 & 0.56 \\
CP & 4.73 & 4.64 & 0.04 & 0.01 \\
Lactose & 10.5 & 10.2 & 0.29 & 0.15 \\
MUN, mg/dL & 100 & 213 & 52.9 & \\
SCC, cells/mL & & & \\
${ }^{1} \mathrm{CON}=\mathrm{control}$ diet; DDGS $=$ diet containing wheat-based dried distillers grains with solubles at $17 \%$ of \\
dietary DM. \\
${ }^{2} \mathrm{ECM}=[0.327 \times$ milk yield $(\mathrm{kg})+12.95 \times$ fat yield $(\mathrm{kg})+7.2 \times$ protein yield]; Tyrrell and Reid $(1965)$.
\end{tabular}


Table 5. Effects of replacing barley grain with wheat dried distillers grains (DDGS) on ruminal pH and rumen fermentation of ruminally cannulated multiparous cows in early lactation ${ }^{1}$

\begin{tabular}{lcccc}
\hline Item & CON & DDGS & SE & $P$-value \\
\hline Ruminal pH & & & & \\
$\quad$ Mean & 6.33 & 6.30 & 0.07 & 0.78 \\
Minimum & 5.60 & 5.67 & 0.07 & 0.52 \\
Maximum & 6.99 & 6.97 & 0.05 & 0.82 \\
pH $<5.8$ & & & & \\
Duration, min/d & 126 & 108 & 49.4 & 0.80 \\
Area, pH $\times$ min/d & 28.8 & 16.6 & 11.3 & 0.53 \\
Total VFA, mM & 107 & 116 & 3.18 & 0.06 \\
VFA profile, mol/100 mol of total VFA & & & & \\
Acetate & 55.8 & 57.0 & 2.23 & 0.07 \\
Propionate & 26.1 & 25.9 & 1.29 & 0.24 \\
Isobutyrate & 0.90 & 0.80 & 0.06 & 0.23 \\
Butyrate & 12.8 & 13.1 & 0.55 & 0.08 \\
Isovalerate & 1.70 & 1.20 & 0.13 & 0.05 \\
Valerate & 2.00 & 1.80 & 0.19 & 0.76 \\
Caproic & 0.61 & 0.60 & 0.05 & 0.99 \\
Rumen $\mathrm{NH}_{3}-\mathrm{N}, \mathrm{mg} / \mathrm{dL}$ & 14.6 & 15.7 & 0.71 & 0.27
\end{tabular}

${ }^{1} \mathrm{CON}=$ control diet; DDGS $=$ diet containing wheat-based dried distillers grains with solubles at $17 \%$ of dietary DM.

decrease as the dietary starch concentration increases because of excess fermentation of starch to VFA in the rumen. Zhang et al. (2010) used DDGS to replace barley grain at $20 \%$ of dietary DM and reported that cows fed the diet with DDGS tended to increase ruminal pH. In addition, Voelker and Allen (2003b) fed beet pulp to replace high-moisture corn at $0,6.1,12.1$, or $24.3 \%$ of dietary DM and found that substituting beet pulp for corn tended to reduce the $\mathrm{pH}$ range. Based on the previous studies, cows fed diets with high-fiber byproducts in place of grain are expected to have a lower risk of rumen acidosis. In the current study, the starch concentration of the DDGS diet was 10 percentage units lower than that of the CON diet. As such, we expected that cows on the DDGS diet would increase ruminal $\mathrm{pH}$.
However, in the current study, ruminal pH was not affected by treatment, although the DDGS diet contained less starch and was expected to ferment to a lesser extent in the rumen. This might be partly attributed to the possible difference in chewing time. Physically effective fiber stimulates chewing behavior and increases the secretion of salivary buffers (Maekawa et al., 2002) that neutralize approximately one-third of fermentation acids in the rumen (Allen, 1997). As such, increased chewing activity is expected to increase ruminal $\mathrm{pH}$ and decrease the risk of ruminal acidosis (Allen, 1997; Yang et al., 2001). In the current study, chewing behavior was not evaluated, but a previous study (Zhang et al., 2010) compared the chewing behavior of cows fed DDGS and those fed barley grain, and reported that chewing time of cows fed DDGS was

Table 6. Effects of replacing barley grain with wheat dried distillers grains (DDGS) on apparent nutrient digestion of ruminally cannulated multiparous cows in early lactation ${ }^{1}$

\begin{tabular}{lcccc}
\hline Item & CON & DDGS & SE & $P$-value \\
\hline Digestibility, \% & & & & \\
DM & 58.0 & 59.9 & 3.05 & 0.67 \\
OM & 62.1 & 63.1 & 3.1 & 0.82 \\
CP & 46.4 & 55.9 & 3.2 & 0.06 \\
NDF & 51.4 & 57.8 & 4.7 & 0.36 \\
Starch & 91.2 & 81.9 & 3.0 & 0.05 \\
Digestion, kg/d & & & & 0.99 \\
DM & 10.5 & 10.5 & 1.06 & 0.86 \\
OM & 10.1 & 9.80 & 0.97 & 0.13 \\
CP & 1.46 & 1.90 & 0.19 & 0.36 \\
NDF & 2.40 & 2.93 & 0.38 & $<0.001$ \\
Starch & 5.00 & 2.66 & 0.31 & \\
\hline
\end{tabular}

${ }^{1} \mathrm{CON}=$ control diet; DDGS = diet containing wheat-based dried distillers grains with solubles at $17 \%$ of dietary DM. 
shorter than that of cows fed barley grain (31.6 vs. 39.1 $\mathrm{min} / \mathrm{kg}$ of DMI; $P=0.01$ ). Cows fed the DDGS diet were expected to have higher ruminal $\mathrm{pH}$ due to lower dietary starch intake in the current study, but the possible lesser chewing time for cows fed DDGS may have counteracted this and might explain why the DDGS diet did not increase ruminal $\mathrm{pH}$.

In addition, $\mathrm{pH}$ of DDGS is often lower than that of grains (Jasaitis et al., 1987; Beliveau and McKinnon, 2009), which might be another reason why the DDGS diet did not increase ruminal pH. Jasaitis et al. (1987) reported that the initial $\mathrm{pH}$ of DDGS was 4.35, whereas that of barley grain was 5.73. Another study (Beliveau and McKinnon, 2009) found that ruminal $\mathrm{pH}$ did not increase with the replacement of barley grain with wheat DDGS, which may be related to the fact that the initial $\mathrm{pH}$ of wheat-based DDGS is lower than the initial $\mathrm{pH}$ of barley grain (4.31 vs. 5.36). The current study did not measure the $\mathrm{pH}$ of wheat DDGS and barley grain, but the greater sulfur content for the DDGS diet (0.54 vs. $0.24 \%$ ) indicated that the initial $\mathrm{pH}$ of wheat DDGS was lower than that of barley grain, possibly because of the addition of sulfuric acid at the ethanol plant, which resulted in similar $\mathrm{pH}$ for both diets despite the lower starch content in the DDGS diet.

The effect of replacing barley grain with DDGS on ruminal $\mathrm{pH}$ is not consistent in the literature. Beliveau and McKinnon (2009) used different amounts of wheat DDGS $(0,7,14$, and $21 \%)$ in place of barley grain in diets of finishing beef cattle and found that treatment did not affect ruminal $\mathrm{pH}$, which is similar to the results of the current study. It might be speculated that the number of cows used in the current study was insufficient to detect treatment effects. However, Penner and Oba (2009) used 5 rumen-cannulated Holstein cows per treatment in their study, using a similar experimental design to that of the current study, and detected a tendency of treatment effects on ruminal $\mathrm{pH}$, and the standard error of mean in their study was similar to that of the current study. In addition, power analysis conducted with SAS software (SAS Institute Inc., Cary, $\mathrm{NC}$ ) showed that a sample size of 6 cows per treatment was required to detect the treatment effect; we used 13 rumen-cannulated Holstein cows $(\mathrm{n}=6$ and 7 for $\mathrm{CON}$ and DDGS group, respectively), which means that the current study had enough statistical power to detect treatment effect on ruminal $\mathrm{pH}$.

\section{Effects on DMI}

Decreasing dietary starch content by partial substitution of dietary grains with wheat DDGS increased DMI of primiparous cows but decreased it for multiparous cows. We had hypothesized that cows fed the DDGS diet would have higher DMI compared with cows on the CON diet, because the DDGS diet contained 10 percentage units less dietary starch than the CON diet and the excess carbohydrate fermentation often decreases DMI of dairy cows. Cows fed rapidly fermentable grain would have lower DMI because of SARA (Nocek, 1997). In addition, excess rumen fermentation may decrease DMI due to greater propionate metabolism in the liver (Allen et al., 2009). In the current study, ruminal $\mathrm{pH}$ and fermentation variables were evaluated for multiparous ruminally cannulated cows, and no effects of treatment on ruminal $\mathrm{pH}$ or propionate concentration were found. As such, the reduction in dietary starch content by partial substitution of dietary grains with DDGS is not expected to increase DMI.

These findings for multiparous cows were similar to previous studies that used high-fiber byproduct to replace grain in dairy diets. Ipharraguerre et al. (2002) used soyhulls to replace corn grain incrementally at 0 , $10,20,30$, and $40 \%$ of DM in the diets of lactating dairy cows, and they found that DMI tended to decrease $(P$ $<0.06)$ linearly. Ranathunga et al. (2010) increased the substitution of DDGS and soyhulls for corn grain to decrease dietary starch concentration $(29,26,23$, and $20 \%$ of dietary DM) and found that DMI decreased linearly when the dietary starch concentration in the diets decreased.

In contrast, partial replacement of dietary grains with wheat DDGS increased DMI of primiparous cows, but the reasons are not known because the ruminally cannulated animals were all multiparous. However, the greater DMI for primiparous cows fed the lower starch diet is consistent with previous findings. Stone (1996) found that multiparous cows increased DMI by $2 \mathrm{~kg} / \mathrm{d}$ when high-moisture corn was replaced with soyhulls at $14 \%$ of dietary DM. Clark and Armentano (1997) showed that feeding beet pulp in place of corn grain at $15.7 \%$ of dietary DM increased DMI. In addition, Janicek et al. (2008) used DDGS to replace both forage and concentrate and found that DMI and milk production increased linearly with increasing dietary allocations of DDGS $(0,10,20$, and 30\%). Using a high-fiber byproduct to replace grain in the diet has inconsistent results, and the causes for these discrepancies are not known.

\section{Effects on Energy Utilization}

In the current study, the reduction in dietary starch content by 10 percentage units did not affect milk yield, and this finding is consistent with some previous research. Clark and Armentano (1997) showed that feeding beet pulp in place of corn grain did not affect milk yield. In another study, diets ranging in nonstruc- 
tural carbohydrates from 24 to $42 \%$ did not affect milk yield and milk fat concentration (Beauchemin et al., 1997). In addition, Voelker and Allen (2003b) used different concentrations of beet pulp $(0,6.1,12.1$, or $24.3 \%$ ) to replace high-moisture corn grain and found no treatment effects on milk production. Furthermore, Ranathunga et al. (2010) used DDGS and soyhulls to replace corn grain and decrease the starch content of experimental diets and found that dietary starch concentration did not affect milk production or composition. Similarly, Zhang et al. (2010) used DDGS as a substitute for barley grain to decrease dietary starch in diets for mid lactation cows, and they did not find treatment effects on DMI and milk yield. Those studies reported that milk production was not affected by dietary starch content.

However, in the current study, apparent total-tract starch digestibility was decreased by more than 9 percentage units for cows fed the DDGS diet. This is consistent with Oba and Allen (2003), who reported that starch digestibility in the rumen and total tract was lower for cows fed low-starch diets compared with those fed high-starch diets. Similarly, Voelker and Allen (2003a) used beet pulp to replace high-moisture corn to decrease dietary starch concentration and found that starch digestibility in the rumen decreased linearly with the increased dietary allocations of beet pulp. The lower starch digestibility for cows fed low-starch diets might be caused by insufficient amylolytic activity in the rumen due to lower dietary starch intake (Oba and Allen, 2003).

Plasma concentration of NEFA is related to how much energy cows mobilize from body reserves and is an indicator for the risk of ketosis (Grummer, 1993). Cows fed the DDGS diet had higher plasma NEFA concentrations, indicating that they mobilized more energy from body reserves. These results may suggest that the DDGS diet supplied less energy compared with the CON diet. Current results indicated that barley grain might be a better energy source to maximize energy intake of dairy cows in the early lactation. van Knegsel et al. (2007) fed glucogenic and lipogenic diets to high-producing dairy cows in early lactation and found that plasma NEFA concentration tended to be lower for cows fed the glucogenic diet compared with cows fed the lipogenic diet. Although treatment did not affect DMI and milk production in their study, these findings indicate that feeding a diet high in glucogenic nutrients resulted in a less-negative energy balance. Nelson et al. (2011) used soyhulls to replace corn meal to make diets with different starch concentrations $(21,23$, and 26\%). They found that cows fed the high-starch diet (26\%) had a lower NEFA concentration than the cows fed the medium- (23\%) or low- (21\%) starch diets. Results of the current study indicate that cows fed the high-starch diet had a lower risk for metabolic disorders such as ketosis and fatty liver.

\section{CONCLUSIONS}

Reducing dietary starch content by partial replacement of dietary grain with wheat DDGS did not affect milk yield, indicating that wheat DDGS could be used as a substitute for barley grain in the diets of dairy cows in early lactation. However, ruminal $\mathrm{pH}$ was not affected by treatment in the current study, which does not support the idea that the use of high-fiber byproduct feedstuffs in place of grains would decrease rumen acidosis of dairy cows in early lactation. In addition, DMI of multiparous cows fed the DDGS diet was lower compared with those fed the CON diet, and plasma NEFA concentration tended to be higher for cows fed the DDGS diet. In addition, cows fed wheat DDGS had a lower apparent total-tract digestibility of starch. Decreasing dietary starch concentration by substituting wheat DDGS for barley grain may be associated with the risk of decreasing energy intake of multiparous dairy cows in early lactation.

\section{ACKNOWLEDGMENTS}

The authors thank E. Subramaniam, L. E. McKeown, A. Ruiz-Sanchez, L. Zhou, N. Schlau, L. Duineveld, R. G. Khorasani and H. Lehman at the University of Alberta (Edmonton, AB, Canada) for their assistance with animal handing and sample collection. This study is supported by Alberta Livestock Meat Agency (Edmonton, AB, Canada), Alberta Milk (Edmonton, AB, Canada), and the Agricultural Bioproducts Innovation Program (Agriculture, Agri-Food Canada, Ottawa, ON, Canada).

\section{REFERENCES}

Allen, M. S. 1997. Relationship between fermentation acid production in the rumen and the requirement for physically effective fiber. J. Dairy Sci. 80:1447-1462.

Allen, M. S. 2000. Effects of diet on short-term regulation of feed intake by lactating dairy cattle. J. Dairy Sci. 83:1598-1624.

Allen, M. S., B. J. Bradford, and M. Oba. 2009. The hepatic oxidation theory of the control of feed intake and its application to ruminants. J. Anim. Sci. 87:3317-3334.

AOAC International. 2002. Official Methods of Analysis. 17th ed. AOAC International, Gaithersburg, MD.

Beauchemin, K. A., L. M. Rode, and W. Z. Yang. 1997. Effects of nonstructural carbohydrates and source of cereal grain in high concentrate diets of dairy cows. J. Dairy Sci. 80:1640-1650.

Beliveau, R. M., and J. J. McKinnon. 2009. Effect of graded levels of wheat-based dried distillers grains with solubles on rumen fermentation in finishing cattle. Can. J. Anim. Sci. 89:513-520.

Canadian Council on Animal Care. 2009. CCAC guidelines on: The care and use of farm animals in research, teaching and testing. CCAC, Ottawa, ON, Canada. 
Clark, P. W., and L. E. Armentano. 1997. Influence of particle size on the effectiveness of beet pulp fiber. J. Dairy Sci. 80:898-904.

Cochran, R. C., D. C. Adams, J. D. Wallace, and M. L. Galyean. 1986. Predicting digestibility of different diets with internal markers: Evaluation of four potential markers. J. Anim. Sci. 63:1476-1483.

Fairfield, A. M., J. C. Plaizier, T. F. Duffield, M. I. Lindinger, R. Bagg, P. Dick, and B. W. McBride. 2007. Effects of prepartum administration of a monensin controlled release capsule on rumen $\mathrm{pH}$, feed intake, and milk production of transition dairy cows. J. Dairy Sci. 90:937-945.

Fawcett, J. K., and J. E. Scott. 1960. A rapid and precise method for the determination of urea. J. Clin. Pathol. 13:156-159.

Grummer, R. R. 1993. Etiology of lipid-related metabolic disorders in periparturient dairy cows. J. Dairy Sci. 76:3882-3896.

Grummer, R. R. 1995. Impact of changes in organic nutrient metabolism on feeding the transition dairy cow. J. Anim. Sci. 73:28202833.

Hayirli, A., R. R. Grummer, E. V. Nordheim, and P. M. Crump. 2002 Animal and dietary factors affecting feed intake during the prefresh transition period in Holsteins. J. Dairy Sci. 85:3430-3443.

Ipharraguerre, I. R., R. R. Ipharraguerre, and J. H. Clark. 2002. Performance of lactating dairy cows fed varying amounts of soy hulls as a replacement for corn grain. J. Dairy Sci. 85:2905-2912.

Janicek, B. N., P. J. Kononoff, A. M. Gehman, and P. H. Doane. 2008. The effect of feeding dried distillers grains plus solubles on milk production and excretion of urinary purine derivatives. J. Dairy Sci. 91:3544-3553

Jasaitis, D. K., J. E. Wohlt, and J. L. Evans. 1987. Influence of feed ion content on buffering capacity of ruminant feedstuffs in vitro. J. Dairy Sci. 70:1391-1403.

Johnson, M. M., and J. P. Peter. 1993. Technical note: An improved method to quantify nonesterified fatty acid in bovine plasma. J. Anim. Sci. 71:753-756.

Karkalas, J. 1985. An improved enzymatic method for the determination of native and modified starch. J. Sci. Food Agric. 36:1019 1027.

Khorasani, G. R., E. K. Okine, and J. J. Kennelly. 1996. Forage source alters nutrient supply to the intestine without influencing milk yield. J. Sci. Food Agric. 76:862-872.

Krause, K. M., and G. R. Oetzel. 2006. Understanding and preventing subacute ruminal acidosis in dairy herds: A review. Anim. Feed Sci. Technol. 126:215-236.

Lammers, B. P., D. R. Buckmaster, and A. J. Heinrichs. 1996. A simple method for the analysis of particle size of forage and total mixed rations. J. Dairy Sci. 79:922-928.

Leonardi, C., and L. E. Armentano. 2003. Effect of quantity, quality, and length of alfalfa hay on selective consumption by dairy cows J. Dairy Sci. 86:557-564.

Maekawa, M., K. A. Beauchemin, and D. A. Christensen. 2002. Effect of concentrate level and feeding management on chewing activities, saliva production, and ruminal $\mathrm{pH}$ of lactating dairy cows. J. Dairy Sci. 85:1165-1175.

Nelson, B. H., K. W. Cotanch, M. P. Carter, H. M. Gauthier, R. E. Clark, P. D. Krawczel, R. J. Grant, K. Yagi, K. Fujita, and H. M. Dann. 2011. Effect of dietary starch content in early lactation on the lactational performance of dairy cows. J. Dairy Sci. 94(ESuppl.):637. (Abstr.)

Nocek, J. E. 1997. Bovine acidosis: Implications on laminitis. J. Dairy Sci. 80:1005-1028.
NRC. 2001. Nutrient Requirements of Dairy Cattle. 7th rev. ed. Natl Acad. Press, Washington, DC

Oba, M., and M. S. Allen. 2003. Effects of corn grain conservation method on ruminal digestion kinetics for lactating dairy cows at two dietary starch concentrations. J. Dairy Sci. 86:184-194.

Penner, G. B., K. A. Beauchemin, and T. Mutsuvangwa. 2006. An evaluation of the accuracy and precision of a stand-alone submersible continuous ruminal pH measurement system. J. Dairy Sci 89:2132-2140.

Penner, G. B., K. A. Beauchemin, and T. Mutsvangwa. 2007. Severity of ruminal acidosis in primiparous Holstein cows during the periparturient period. J. Dairy Sci. 90:365-375.

Penner, G. B., and M. Oba. 2009. Increasing dietary sugar concentration may improve dry matter intake, ruminal fermentation, and productivity of dairy cows in the postpartum phase of the transition period. J. Dairy Sci. 92:3341-3353.

Ranathunga, S. D., K. F. Kalscheur, A. R. Hippen, and D. J. Schingoethe. 2010. Replacement of starch from corn with nonforage fiber from distillers grains and soy hulls in diets of lactating dairy cows. J. Dairy Sci. 93:1086-1097.

Rhee, K. C. 2005. Determination of total nitrogen. Pages 105-113 in Handbook of Food Analytical Chemistry: Water, Proteins, Enzymes, Lipids, and Carbohydrates. R. E. Wrolstad, E. A. Decker, S. J. Schwartz, and P. Sporns, ed. John Wiley and Sons, Hoboken, N.J.

Schingoethe, D. J., K. F. Kalscheur, A. R. Hippen, and A. D. Garcia. 2009. Invited review: The use of distillers products in dairy cattle diets. J. Dairy Sci. 92:5802-5813.

Stone, W. C. 1996. Applied topics in dairy cattle nutrition. 1. Soy hulls as either forage or concentrate replacement. PhD Thesis. Cornell Univ., Ithaca, NY.

Tyrrell, H. F., and J. T. Reid. 1965. Prediction of the energy value of cow's milk. J. Dairy Sci. 48:1215-1223.

van Knegsel, A. T., M. H. van den Brand, E. A. M. Graat, J. Dijkstra, R. Jorritsma, E. Decuypere, S. Tamminga, and B. Kemp. 2007. Dietary energy source in dairy cows in early lactation: Metabolites and metabolic hormones. J. Dairy Sci. 90:1477-1485.

Van Soest, P. J., J. B. Robertson, and B. A. Lewis. 1991. Methods for dietary fiber, neutral detergent fiber and nonstarch polysaccharides in relation to animal nutrition. J. Dairy Sci. 74:3583-3597.

Voelker, J. A., and M. S. Allen. 2003a. Pelleted beet pulp substituted for high-moisture corn: 2. Effects on digestion and ruminal digestion kinetics in lactating dairy cows. J. Dairy Sci. 86:3553-3561.

Voelker, J. A., and M. S. Allen. 2003b. Pelleted beet pulp substituted for high-moisture corn: 3. Effects on ruminal fermentation, $\mathrm{pH}$, and microbial protein efficiency in lactating dairy cows. J. Dairy Sci. 86:3562-3570.

Wildman, E. E., G. M. Jones, P. E. Wagner, R. L. Boman, H. F. Troutt Jr., and T. N. Lesch. 1982. A dairy cow body condition scoring system and its relationship to selected production characteristics. J. Dairy Sci. 65:495-501.

Yang, W. Z., K. A. Beauchemin, and L. M. Rode. 2001. Effects of grain processing, forage to concentrate ratio, and forage particle size on rumen $\mathrm{pH}$ and digestion by dairy cows. J. Dairy Sci. 84:2203-2216

Zhang, S. Z., G. B. Penner, W. Z. Yang, and M. Oba. 2010. Effects of partially replacing barley silage or barley grain with dried distillers grains with solubles on rumen fermentation and milk production of lactating dairy cows. J. Dairy Sci. 93:3231-3242. 